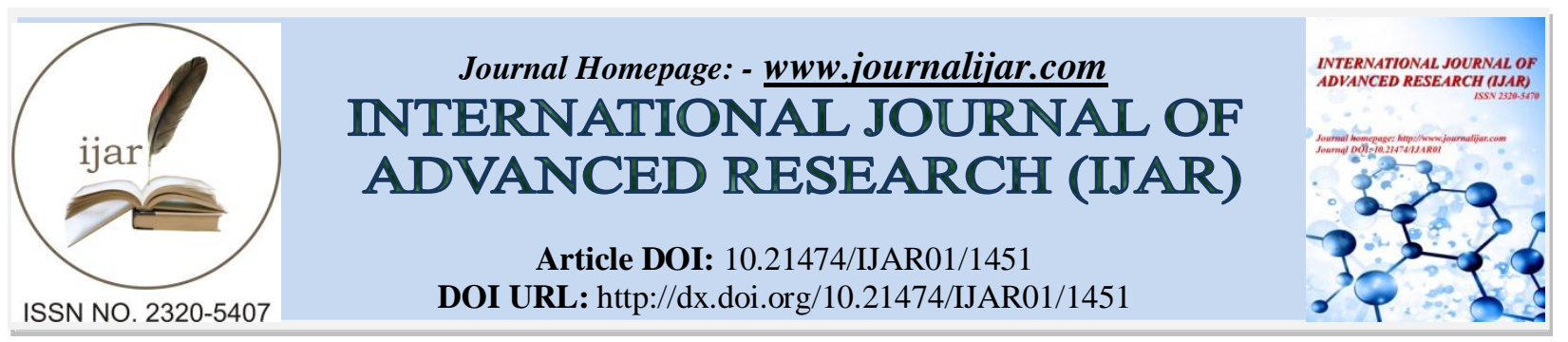

RESEARCH ARTICLE

\title{
CONTAMINATION TRANSPORT IN GROUNDWATER FROM MUNICIPAL SOLID WASTE LANDFILL POLLUTANTS.
}

\author{
"Parthiban L and Dr. Amit B. Mahindrakar. \\ Scale, VIT University.
}

\section{Manuscript Info}

Manuscript History

Received: 16 July 2016

Final Accepted: 19 August 2016

Published: September 2016

Key words:-

Municipal Solid Waste, Leachate,

Contamination, Transport, Monsoon

Variation.
Abstract

Waste disposal management stays one of the primary challenges in India. Wastes, if not properly disposed could lead to pollution of surface and subsurface water in its urge environment. Expanded interest in municipal and industrial facilities due to over population has brought about the increasing number of solid waste generation. This study is conducted to evaluate the groundwater quality framework around two dumpsites present in Ranipet and Walaja in Vellore District, Tamilnadu located in India. Based on the findings from this study, the concentration of various physico-chemical parameters Such as conductivity, TDS, Chloride, Sulfate, Phosphate, Nitrate, BOD, COD, Nickel, Lead, Copper, Manganese, Chromium, Cadmium, Zinc, Iron, Potassium \& Calcium were recorded at all the sampling sites. Leachate was characterized by high contents of natural and inorganic chemicals and the toxic nature increasing from heavy metals concentrations, the higher concentration of Heavy metals like Chromium, Cadmium and Lead in the water samples of bore well shows the penetration of landfill leachate has occurred to the subsurface water. This study is done to evaluate the groundwater quality framework in two dumpsites located in Vellore District, Tamilnadu.

Copy Right, IJAR, 2016,. All rights reserved.

\section{Introduction:-}

Landfills have been considered as one of the serious danger to groundwater resources all through the world. During rainfall, the solid waste responds with water and deteriorates to shape a risky liquid called 'Leachate'. It contains enormous measure of natural matter (biodegradable and non-biodegradable), inorganic poisons, heavy metals and so on. It is a genuine danger to groundwater and thus to the nature. The contamination of groundwater by leachate will bring about unfriendly consequences for human. The most widely recognized risk to the human from these landfills is from the use of groundwater that has been influenced by leachate. The MSW dumped in landfills or open dumps are subjected to either groundwater interruption, precipitation or some other conceivable of infiltration of water into the ground. The impacts of landfill leachate on groundwater and its effect on the earth have increased more consideration as of late. Number of exploration has been led on MSW dumping because of urbanization. The spots adjacent to landfill are under genuine anxiety because of the immediate effect of leachate and there are various procedures that can be used to overview the groundwater quality. Over the past years, heavy metals have significantly harmed the groundwater quality and expanded natural contamination from rural metropolitan sources. Contaminants like $\mathrm{Cd}, \mathrm{Cu}, \mathrm{Ni}, \mathrm{Pb}, \mathrm{Zn}$, and so on enters the groundwater. In this study the scope of ground water 
pollution because of interruption of leachate on ground water around two dump sites are examined. This study was completed to evaluate the groundwater quality around dumpsite in Vellore, Tamilnadu.

\section{Methodology:-}

Leachate samples were gathered from two unique Locations in every site and broke down to survey their qualities and soundness. Groundwater samples were gathered from sixteen bore wells, eight at every site, around the landfills and inside $500 \mathrm{~m}$ range from the dumpsite keeping in mind the end goal to monitor the nearer aquifer degree of contamination. Examining was directed at two unique storms i.e. Pre-monsoon (April to July) and Post-monsoon (October to December). All the specimens were gathered and safeguarded then analyzed by Standard Methods for the Examination of Water. The samples were tried for toxins like organic contaminants for example, Biochemical Oxygen Demand (BOD) and Chemical Oxygen Demand (COD), ammonia, nitrates, nitrogen, suspended solids and heavy metals. heavy metals like nickel $(\mathrm{Ni})$, lead $(\mathrm{Pb})$, copper $(\mathrm{Cu})$, manganese $(\mathrm{Mn})$, chromium $(\mathrm{Cr})$, cadmium $(\mathrm{Cd})$, zinc $(\mathrm{Zn})$, and iron $(\mathrm{Fe})$ were picked as a result of their presence in landfill leachate.

\section{Results and Discussion:-}

The Leachate samples and Groundwater samples were collected from both Ranipet and Walaja dumpsite and analyzed to assess their physico-chemical characteristics and heavy metal analysis. Sampling was conducted at two different monsoons i.e. Pre-monsoon (April to July) \& Post-monsoon (October to December). All the samples were collected, preserved, and analyzed according to the Standard Analytical Methods for the Examination of Water and Wastewater.

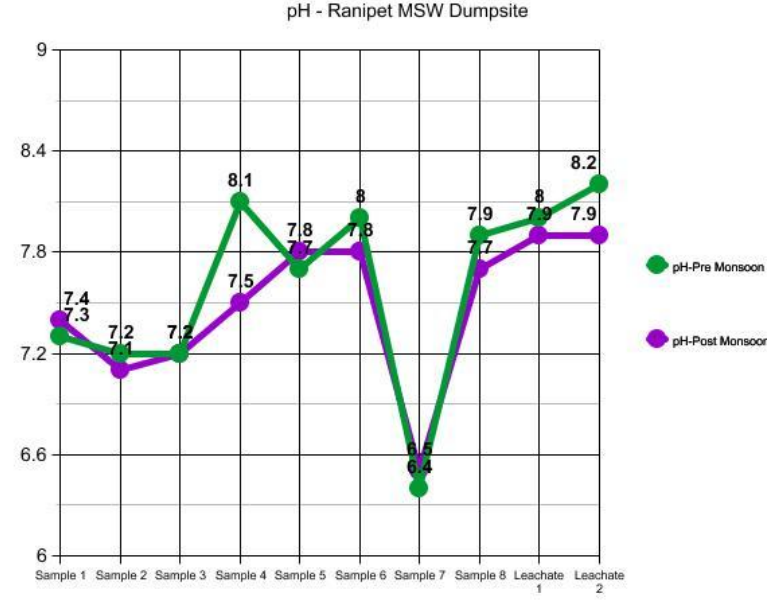

Fig.1:- Ranipet pH Graph .

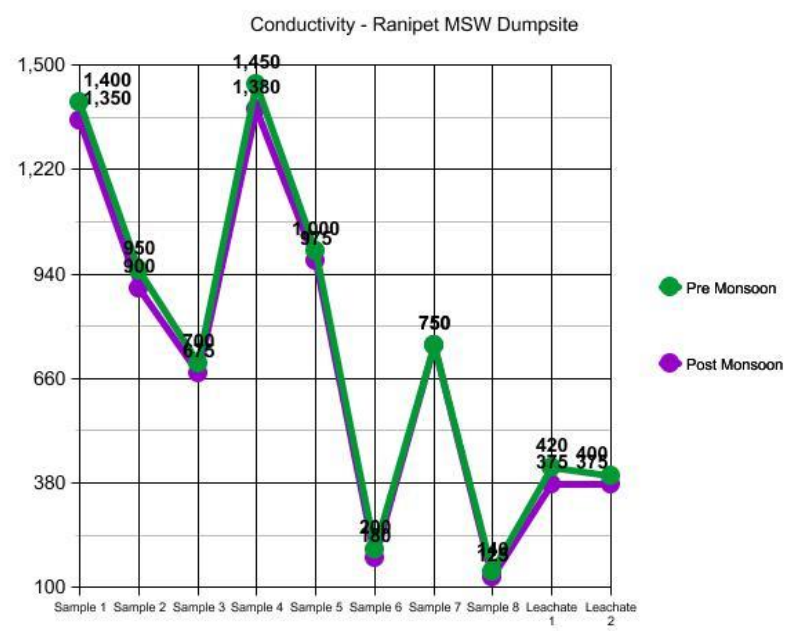

Fig.3:- Ranipet Conductivity Graph

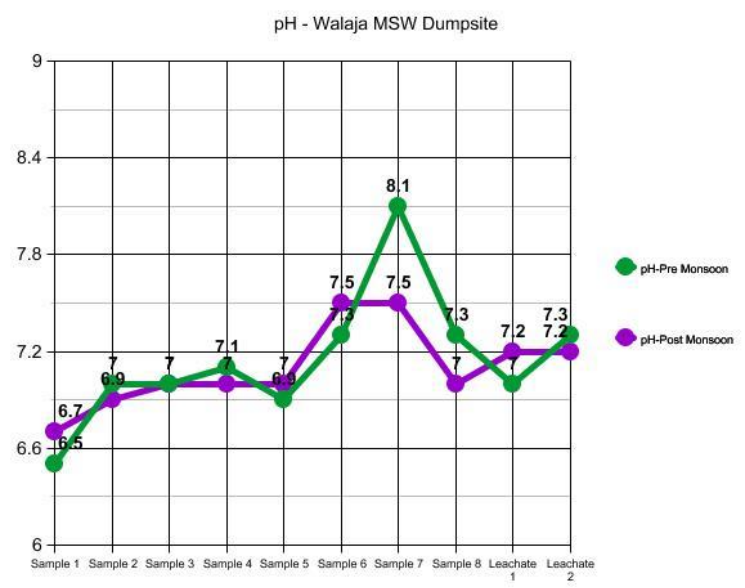

Fig.2:- Walaja pH Graph.

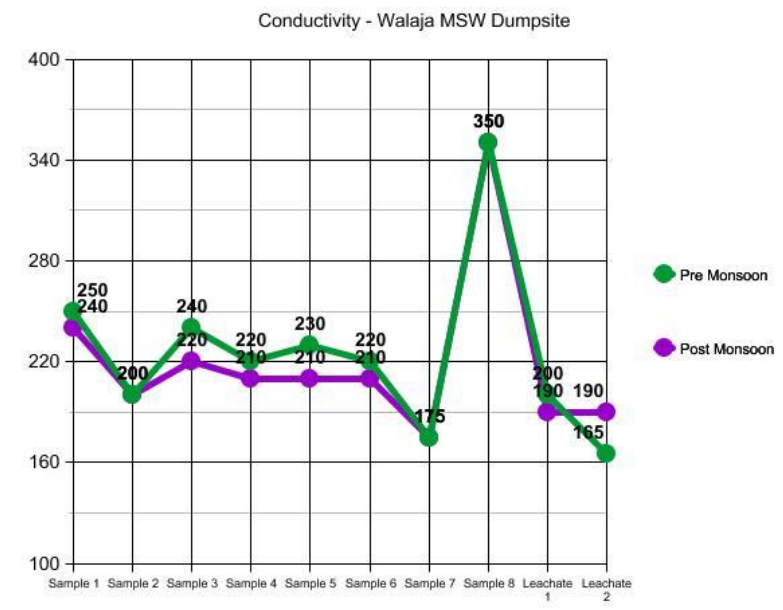

Fig.4:- Walaja Conductivity Graph 
TDS - Ranipet MSW Dumpsite

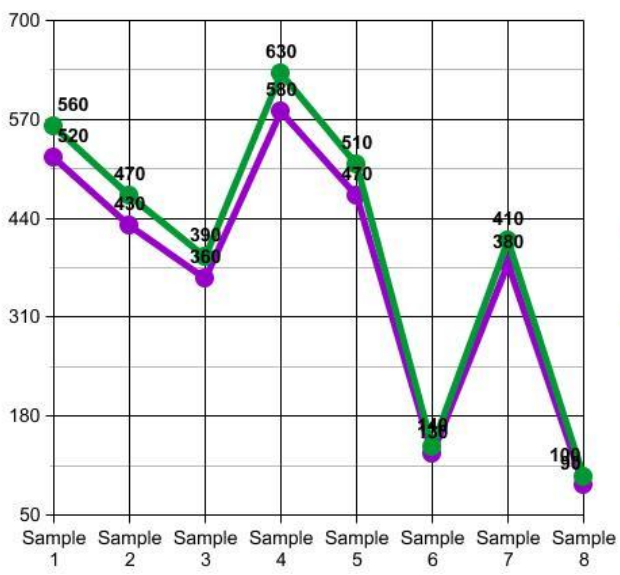

Fig.5:- Ranipet TDS Graph

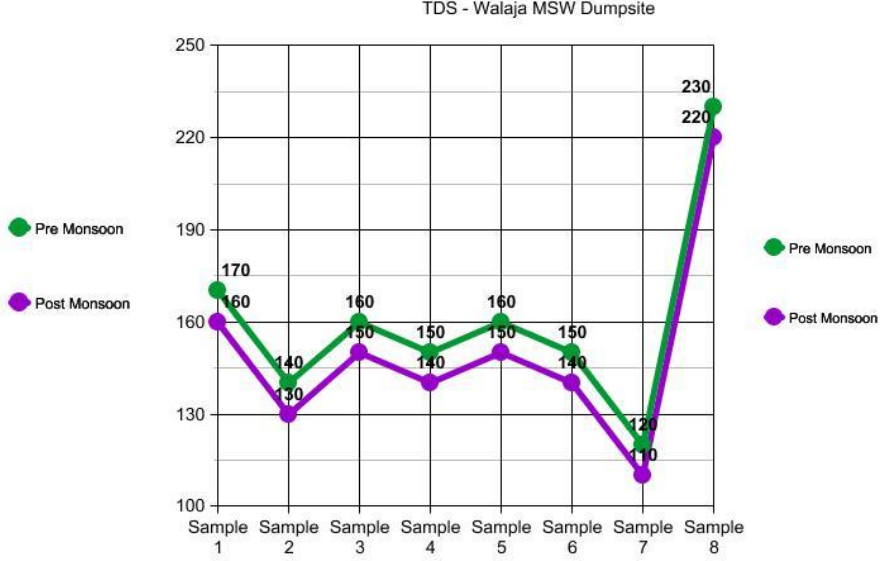

Fig.6:- Walaja TDS Graph

Chromium - Ranipet MSW Dumpsite

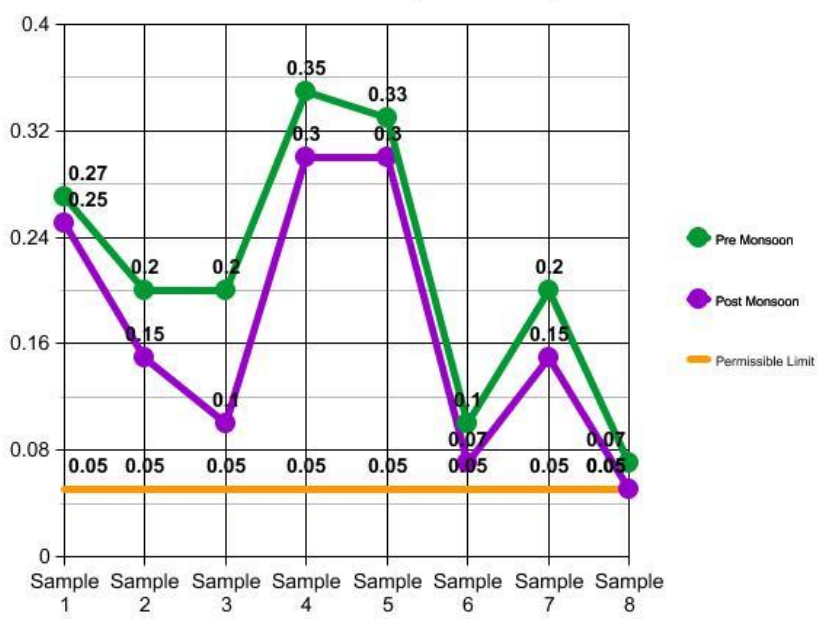

Fig.7:- Ranipet Chromium Graph.

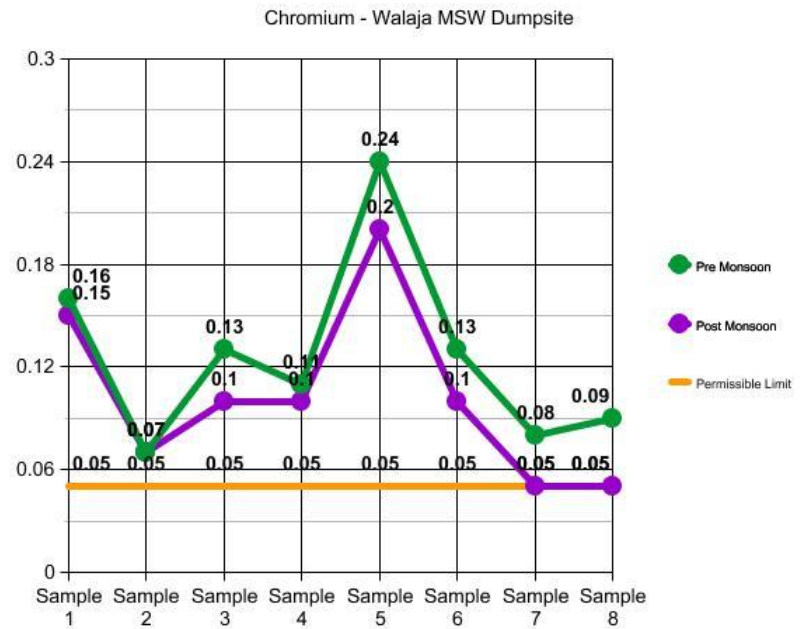

Fig.8:- Walaja Chromium Graph. 


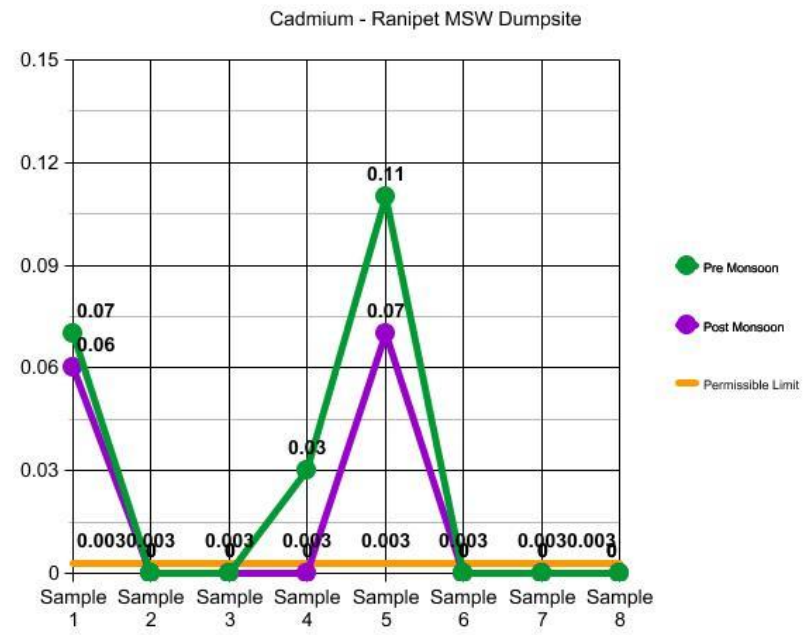

Fig.9:- Ranipet Cadmium Graph

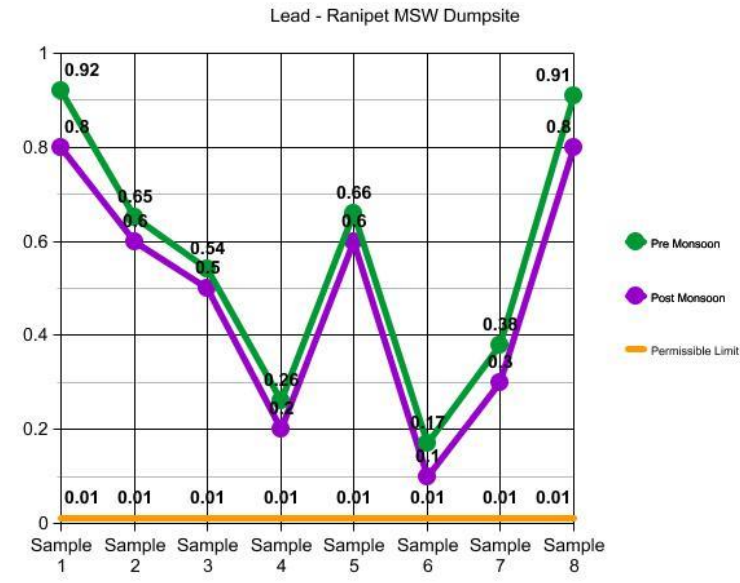

Fig.10:- Ranipet Lead Graph

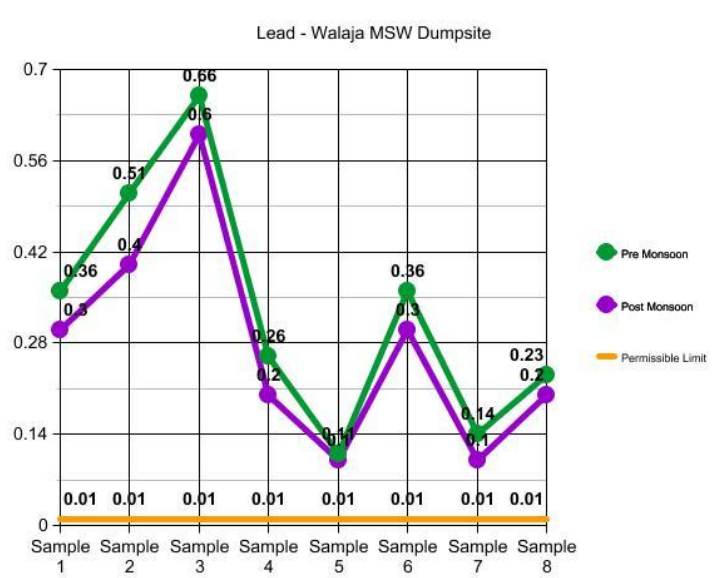

Fig.11:- Walaja Lead Graph

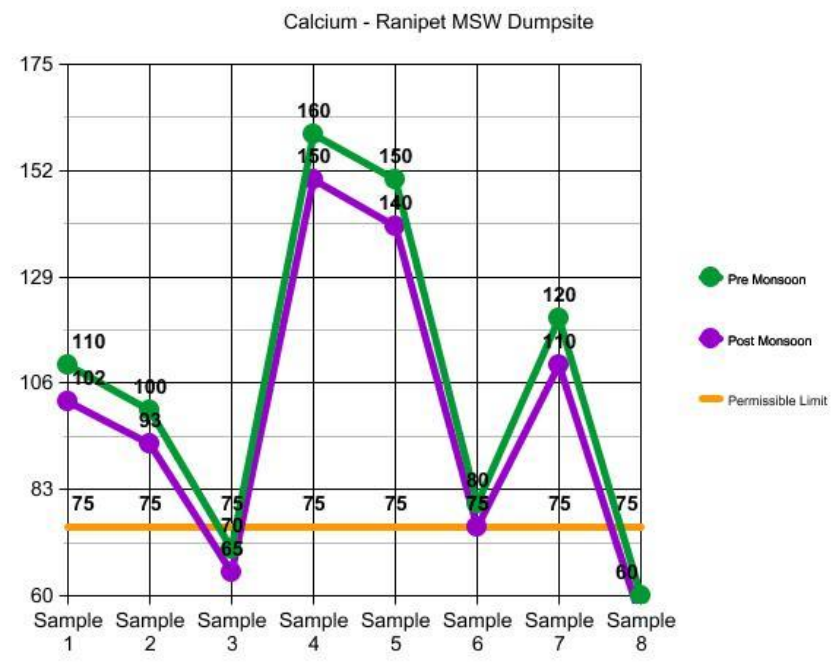

Fig.12:- Ranipet Calcium Graph 


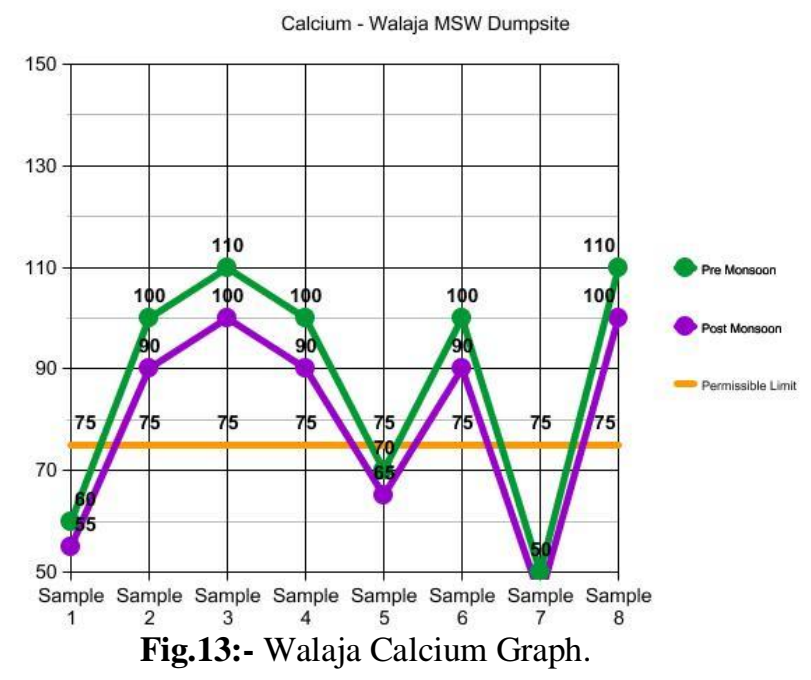

\section{Conclusion:-}

The fundamental environmental concern in this study is the impact of landfills leachate on the groundwater quality. It is clear that the Solid waste dumping destinations in Vellore District is discovered prone to the ground water pollution through draining activity. In view of the findings from this study, the grouping of different physicochemical parameters Such as conductivity, TDS, Chloride, Sulfate, Phosphate, Nitrate, BOD, COD, Ni, Pb, Cu, Mg, $\mathrm{Cr}, \mathrm{Cd}, \mathrm{Zn}, \mathrm{Fe}$, Potassium and $\mathrm{Ca}$ were recorded at all the inspecting destinations. Leachate was described by high substance of natural and inorganic chemicals and in addition the poisonous nature emerging from heavy metals, the higher concentration of Heavy metals like Chromium, Cadmium and Lead in the water tests of bore well demonstrates the entrance of landfill leachate into the subsurface water. Thus we can reason that unless proper measures to control the pollution of leachate from the dumpsite are not taken there will be a threat to the subsurface water. Despite the fact that the concentration of a few different parameters in ground water is inside allowable points of contamination yet it is huge and it is must that ground water should be free from any sort of contaminants. Consequently, there is a need of experimental administration of the dumping sites to prevent ground water defilement and the customary observing of the ground water in and around zones of landfill dumping destinations is required. Additionally, if the dumping is ceased quickly, the groundwater quality will enhance in couple of years by natural means because of ground water recharge and flushing.

\section{References:-}

1. APHA (1992) Standard Methods for Examination of water and waste water. $18^{\text {th }}$ Edition, American Public Health Association.

2. Central Pollution Control Board (CPCB) (2010) Tamilnadu Pollution Control Board - Revised action plan for critically polluted area - Ranipet November 2010.

3. C.J. Smith, P. Hopmans, F.J. Cook (1996) Accumulation of $\mathrm{Cr}, \mathrm{Pb}, \mathrm{Cu}, \mathrm{Ni}, \mathrm{Zn}$ and $\mathrm{Cd}$ in soil following irrigation with treated urban effluent in Australia, Environmental Pollution. 94 (3), pp. 317-323

4. Chatterjee R (2010) Municipal solid waste management in kohima city-india. Iran Journal of Environmental health science and engineering. 7(2):173-180.

5. Craig Clifton, Rick Evans, Susan Hayes, Rafik Hirji, Gabrielle Puz, Carolina Pizarro (2010) Water and Climate Change: Impacts on groundwater resources and adaptation options. Water Working Notes. Note No. 25: 18

6. Dan Ma, Haibo Bai (2015) Groundwater inflow prediction model of karst collapse pillar: a case study for mining-induced groundwater inrush risk. Natural Hazards 76:1319-1334 DOI 10.1007/s11069-014-1551-3.

7. DANIELA DUCCI (1999) GIS Techniques for Mapping Groundwater Contamination Risk. Natural Hazards 20: 279-294.

8. Deepankar Choudhury, Purnanand Savoikar (2011) Seismic yield accelerations of MSW landfills by pseudodynamic approach. Natural Hazards 56:275-297 DOI 10.1007/s11069-010-9568-8.

9. E O Longe,M R Balogun, 2010, Groundwater Quality Assessment near a Municipal Landfill, Lagos , Nigeria, Research Journal of Applied Sciences, Engineering and Technology.

10. F. Huang, G. H. Wang, Y. Y. Yang, C. B. Wang (2014) Overexploitation status of groundwater and induced geological hazards in China. Natural Hazards 73:727-741 DOI 10.1007/s11069-014-1102-y. 
11. G.S.R. Karishnamurti, R. Naidu (2003) Solid-solution equilibria of cadmium in soils, Geoderma, 113, pp. 1730.

12. L. W. Canter, R. C. Knox and D. M. Fairchild (1988) Groundwater Quality Protection. Chelsea, MI: Lewis Publishers.

13. Lee, G. Fred and A. R. Jones (1991) "Groundwater Pollution by Municipal Landfills: Leachate Composition, Detection and Its Water Quality Significance." Proceedings of the National Water Well Association Fifth National Outdoor Action Conference, Las Vegas, NV.

14. Lee, G. Fred and A. R. Jones "Landfills and Groundwater Quality." Groundwater 29 (1991):482-486.

15. Luwang Chen, Xiaoxi Yin, Wenpin Xie, Xiaoqing Feng (2014) Calculating groundwater mixing ratios in groundwaterinrushing aquifers based on environmental stable isotopes (D, 18O) and hydrogeochemistry. Natural Hazards 71:937-953 DOI 10.1007/s11069-013-0941-2. 